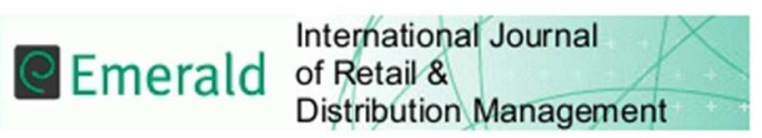

\title{
Improving UK retail academic-practitioner research: insights from relationship marketing
}

\begin{tabular}{|r|l|}
\hline Journal: & International Journal of Retail \& Distribution Management \\
\hline Manuscript ID & IJRDM-01-2016-0009.R3 \\
\hline Manuscript Type: & Research Paper \\
\hline Keywords: & retail, academic-practitioner gap, impact, relationship marketing \\
\hline \multicolumn{2}{|l}{} \\
\hline
\end{tabular}

SCHOLARONE ${ }^{\text {Ix }}$

Manuscripts 


\title{
Improving UK retail academic-practitioner research: insights from relationship marketing
}

\begin{abstract}
Purpose: This paper explores the reasons for the continuing 'gap' between UK retail academic research and practice. A Relationship Marketing (RM) lens, focusing on relationship antecedents, is used to develop a deeper understanding of the barriers to collaboration and propose new solutions to close the gap.
\end{abstract}

Design: The paper adopts a qualitative methodology to compile the evidence, using multiple data sources to identify the dynamics of the retail academic-practitioner divide.

Findings: The research illustrates a marked absence of the majority of the customerfocused, seller focused and dyadic antecedents, essential for effective relational exchanges, and highlights that at the heart of the problem lies a lack of shared understanding of mutual relationship benefits with academics currently neither motivated nor incentivised to develop such relationships.

Research implications: Further research is needed to explore what characterises a successful sustainable research relationship. There is also a pressing need to understand the experience, skills and knowledge of 'boundary spanners' who operate successfully in both academic and business cultures.

Practical Implications: Universities should adopt a strategic approach towards building relationships with retailers based upon relationship antecedents. Reward structures should be developed to encourage academics to develop research relationships. Resources should be allocated to better defining and communicating the benefits of a university research relationship with retailers.

Originality/value: There has been limited empirical research on the academic-practitioner gap within the context of the UK retail sector. The RM lens draws attention to new insights about barriers to successful relationships and generates concrete ideas for closing the gap moving forward.

Keywords: Retail, academic-practitioner gap, impact, relationship marketing

Paper type: Research

Word count: 8077

\section{Introduction}

The 'gap' between research and practice is not a new phenomenon but the case for improving UK academic-practitioner research relationships in retailing is particularly compelling. With annual sales totalling $£ 311 \mathrm{bn}$ (equivalent to $20 \%$ of UK GDP), employing one in nine working people, and the 6th largest retail sector in the world by sales, UK retailing is considered to be central to the economic and social wellbeing of the nation and one of the world's most competitive and innovative industries (BIS, 2012; 2013). In recent 
years, there has been the demise of some well-known retail brands due to a slow response to the dramatic social and technological changes taking place within the retail environment. Most notable has been a failure to respond to the multi-channel challenge presented by the growth of the internet as well as significant demographic changes impacting the competitive shape of the global retail marketplace. UK Retailing has been described as a sector 'in crisis' (Guardian, 2011) in need of a strong research capability to generate strategic insights and innovative business models to enable managers to confront the challenges head on.

The Economic and Social Research Council (ESRC), the UK's largest social science research funding body, has commissioned two studies in the last seven years to scope contemporary and future management challenges in the UK Retail Sector. Both studies identified that although there is a significant level of academic research, which is of relevance to retailers, more value is placed on research produced by commercial consultancies than academic departments (Wood et al, 2008). The ESRC funded Retail Knowledge Navigator project documents the existence of several barriers to research collaboration attributed to academic attitudes and behaviour as well as retailer ambivalence towards academic research (Cassidy et al, 2013). Despite the importance of research 'impact' within the Research Excellence Framework (REF) very little progress appears to have been made getting academics and practitioners to work together on collaborative retail research activity.

\section{Aim and Objectives}

The aim of this study is to develop our understanding of the continuing 'gap' between retail academic research and practice. The objectives are to:

- Identify the barriers to effective retail research relationships as articulated by academics and practitioners.

- Generate new insights about the 'gap' by considering these barriers through a 'relationship marketing' (RM) lens.

- Identify potential solutions to help close this gap and enable relevant academic research to meaningfully impact current and future retail practice.

To achieve these objectives a qualitative, exploratory research approach was adopted drawing on two data sources; a review of relevant secondary literature including retail policy and practice documents, and findings from in-depth interviews with a sample of eight retail executives and nine senior retail academics. The data is analysed using a template derived from the RM antecedents defined in the Relational Mediator Meta-Analytic Framework (RMMF) developed by Palmatier et al (2006).

The paper is structured as follows. An outline of the characteristics of the retail context and what we know already about the research problem i.e. the barriers to research collaboration is provided. This is followed by a discussion of the relevant RM theory and framework used to explore the case and then an outline of methodology. The findings and discussion tease out relevant issues supported by evidence from the dataset. The conclusion and implications for practice outlines action for Universities to develop relationships between academics and retailers and highlights directions for further research. 
The Retail context and the 'research' problem

The retail sector is the largest private sector employer in the UK and includes a wide range of different professions such as marketing, logistics, finance, law and human resource management. The sector employs around 3 million people, over $10 \%$ of the UK workforce and is therefore seen by the UK Government as an important social force (Burt, Sparks and Teller, 2010). The sector plays a 'vital role in our communities as a provider of employment, of the goods and services people want and need and a force for social cohesion'(BIS, 2013, p.2). Retailers are currently facing significant environmental, economic and social challenges brought about by change in consumer behaviours stimulated by technological innovation. There is intense competition amongst retailers for a profitable share of consumers' disposable and 'low inflation means downwards pressure on margins' (Racontuer - Future of Retail 21 June 2015, p1). The BRC-Nielsen Shop Price Index (SPI), a monthly measure of UK shop price inflation, reported 28 consecutive months of falling shop prices to August 2015. (www.brc.org.uk). This is a significant challenge at a time when UK retail is faced with additional costs, for example from the introduction of a National living wage, increase in business rates and apprenticeship levy which will add $f 14 \mathrm{bn}$ of costs onto the retail industry in the next four years - amounting to approximately $20 \%$ of industry profitability (Racontuer - Future of Retail 29 May 2016, p1). The British Retail Consortium report that between 2004 and 2014 , costs in the UK retail industry rose $33.8 \%$ but consumer spending only increased by $2 \%$ (Racontuer - Future of Retail 29 May 2016, p1).

On-line shopping is now an integral element of consumers' repertoire, accompanied by regular use of on-line reviews, comparison sites and discount voucher or code sites (MintelOxygen, 2011). 70\% of UK shoppers own a smartphone (Talk-retail.co.uk) and are comfortable using this device to shop. However, despite the rapid expansion of this new multichannel reality, only $29 \%$ of UK retailers consider themselves to be omni-channel (Racontuer -Future of Retail 21 June 2015, p.3), with many appearing to have been reluctant (and slow) to embrace the commercial opportunities opening up in the digital space. Other retail trends, including annual discounting events such as Black Friday in late November, and Cyber Monday in early December, have added to the challenge of matching supply to demand. Further challenges facing the sector include skills shortages, security concerns and demands for more sustainable and responsible retail practices.

As noted by Wood et al (2008) there is a great deal of academic research being carried out which could potentially help retailers confront these challenges head on. They claim that 'academic work is vastly underutilised in the retail commercial context' (section 3.9). The potential for collaboration was highlighted further by Cassidy et al (2013) who illustrated how the retail challenges could be readily mapped onto the generic research priorities of the Economic and Social Research Council (ESRC). Their research highlighted seven key retail agendas, which presented opportunities for collaborative research investment including sustainable and responsible retailing, omni channel retailing, internationalisation, consumer insights, retail employment (skills and development), the future of the high street and the changing structure of physical retail space and innovation (Cassidy et al, 2013, p.31). All of these agendas linked in some way to the ESRC priorities. Despite the synergy between the two sets of research priorities however, there remains a perceived lack of a strong 
retailer/academic research relationship with very little collaborative research taking place in practice.

\section{The Academic 'Gap'}

A number of barriers have been identified to explain the lack of strategic research collaboration. First; there appears to be a lack of awareness of the existence of large clusters of retail related research amongst the retail practitioner community. As Wood et al (2008, p.66) note, it 'is misguided to believe that retailers or the wider interested community ever pick up an academic journal. In the main, the industry does not have time to search around for such potentially relevant information'. Much research within the sector tends to focus on commercialisation with less awareness of the potential impact and value of other services i.e. data capture and development and network facilitation and development. Faced with a research problem, retailers turn to commercial data providers for information rather than academics. Retailers also appear to be uncertain about how to access academic research, i.e. to identify which universities have expertise in which areas. For their part, academics readily admit to this 'access' problem. The pressure to publish in high ranking academic journals, reinforced through the Research Excellence Framework (REF), which focus primarily on theoretical contributions (Nkomo, 2009), often means that findings are inaccessible to practicing retailers and does not reflect current issues or priorities. As well as the fact that academics appear to be using inappropriate channels to communicate research to practitioners, there is a concern about how the messages are formulated and presented. In most cases the format and presentation of research material conforms to the style protocols of academic journals stressing rigor over relevance, which renders it incomprehensible to practitioners (Baron et al, 2011).

Second; and possibly a more problematic issue, is a perceived scepticism amongst practicing retailers about the relevance, impact and timescales associated with much of the traditional academic research. Complaints from retailers that academic outputs are overly theoretical and abstract and do not deal with the operational problems retailers are facing on a day to day basis are commonplace. The abstract nature of content is often combined with concerns over the length of time it takes for the results to be produced. In their defence, academics claim that it takes time to produce high quality, rigorous outputs but leads to superior benefits in the long term in terms of better quality of decision making. The result of this is that in the 1960's, practitioners in the marketing field authored or co-authored over $40 \%$ of research articles published in leading academic journals but, according to Hubbard and Lindsay, by 2002 this figure had dropped to 14\% (see Geuens 2011p.1104) and the perceived relevance to practitioners of academic research had 'decreased in almost direct proportion to improvements in rigour' (Bartunek 2011, p. 555).

As noted above, these barriers are not unique to the retail sector and have been put forward to explain the existence of an academic-practitioner research divide more generally in Marketing and Management. The views of the academic members of the editorial board of the European Journal of Marketing were represented in an editorial in 2010 focused on nature of the 'long debated 'theory-practice' divide in marketing scholarship (Lee and Greenley, 2010). Although there was disagreement at a philosophical level about the role of academic research, there was widespread agreement that the content of scholarly journals was largely inaccessible to managers and practitioners and that academics were facing increasing pressure from funding bodies to demonstrate the social and economic impact of 
their research endeavour moving forward, making collaboration and co-operation highly desirable.

The different views held by practitioners and academics about the role, value and relevance of research has frequently been referred to in the management literature as the 'research to practice' knowledge gap which limits the transfer of academic knowledge to practitioners. The 'gap' has been given a variety of labels including the 'academicpractitioner' gap (Hughes et al, 2008) 'the 'science-practice' gap (Rynes et al, 2007) and the 'knowing-doing' gap (Pfeffer and Sutton 1999). Markides (2007) refers to two translation gaps, with one, lost 'in' translation highlighting dissemination problems and the second lost 'before' translation referring to research which does not relate appropriately to practice.

According to the recent Dowling Review of Business-University Research Collaborations (2015) 'despite the fact that there are many successful examples of research collaborations between business and academia in the UK, overall, performance in achieving such collaborations is patchy, meaning that the UK is potentially missing out on both the new research insights and the productivity benefits that collaboration can bring' (p.65) Although the academic-practitioner research gap is not a new problem our contribution in this paper is to investigate research collaborations in the UK retail sector, a major contributor to UK productivity. Our novel RM lens generates a deeper understanding of the issues, offers a number of new insights about the barriers to collaboration and provides new suggestions about ways to close the gap.

\section{The effectiveness of relationships: the marketing perspective}

Relationship marketing (RM) has been defined as 'establishing, developing and maintaining successful relational exchanges' (Morgan and Hunt 1994, p.22). In a recent review of empirical and academic perspectives on RM, Sheth $(2015, p .4)$ identified five areas which have been the focus of academic attention since its appearance in the marketing lexicon; loyalty programmes, customer satisfaction, bundling and share of wallet, key account management and industrial marketing. These represent very specific marketing activities. Hunt (2010) however presents RM (or relational strength) on a more strategic level as a potential resource advantage for a firm. Vincent and Webster (2013) note that RM constructs have been applied to a variety of relationships including service relationships; buyer and seller relationships; not-for-profit relationships; organisational relationships; channel relationships; business-to-business relationships; and employee relationships. Academics have also explored the value of RM in a variety of contexts, from membership associations (Vincent and Webster, 2013) to marriage (Tynan, 1997).

The Dowling Review (2015) identified 'strong personal relationships' to be 'at the heart of any successful collaboration'. (p.28). A relationship marketing lens, with an emphasis on personal constructs such as trust, commitment and integration, was considered to be particularly appropriate here to generate new insights about barriers to effective collaboration.

Palmatier et al (2006) provide an integrated understanding of RM from a meta-analysis of RM studies from 1987 to 2004 resulting in The Relational Mediator Meta-Analytic Framework (RMMF) Table 1 below highlights the key antecedents to relationships identified 
in the original framework. Palmatier's research highlights the link between antecedents, relational mediators and moderators and performance outcomes and demonstrates that the most effective antecedents for RM are expertise and dyadic communication followed by relationship specific investment. Whilst acknowledging the complexity of relationships, our interest with this exploratory project is simply to assess the existence of customer and seller focused and dyadic antecedents in the context of the retail academic-practitioner relationship, the left hand side column of the framework. Reference to the RMMF is considered particular appropriate here as Palmatier's research stresses the importance of acknowledging the exchange context of the relationship, in this case, the dynamic and turbulent UK retail environment as discussed above. In the context of this paper, 'sellers' are defined as those institutions, research groups and academics involved in retail research. The 'buyers' or 'customers' are represented by UK retail organisations, retailers and senior retail practitioners. Drawing on the customer focused, seller focused and dyadic antecedents outlined in the RMMF, Table 1 highlights the range of questions which might be explored in the context of the retail academic-practitioner research relationship.

\section{INSERT TABLE 1 HERE}

This study explores the implications of using RM theory for the development of an effective and sustainable long term research exchange relationship between retail academics and practitioners and the potential of a RM focus to guide strategy development and provide a resource advantage for a firm (Morgan and Hunt 2010). The justification for the adoption of this approach therefore lies not only in the recognised need for strong relationships between both parties but the potential of the RM lens to generate new insights into what continues to be an enduring issue at a time when the case for improving UK academicpractitioner research relationships in retailing is particularly compelling.

\section{Methodology}

The aim of the study was to develop our understanding of the 'gap' between retail academic research and practice and to evaluate the issues and identify potential solutions to close this gap using a RM lens. To achieve this we adopted a qualitative, exploratory approach as this places emphasis on examining participant interpretations and takes account of the research context (O'Donnell and Cummins, 1999; Fisher, 2007). Qualitative research also enables the researcher to gain a detailed understanding of the complex phenomena to be investigated in order to build theory (Bryman, 2008). The study used two data sources. First, information obtained from relevant retail policy and practice publications, including company reports and websites. Of particular note here was the information from two ESRC studies commissioned since 2008, which have explicitly explored the retail academic-practitioner divide, the Retail Navigator project (2012-2014) and the Business Engagement project (2008). Second, and more significantly, the findings study involving in depth interviews with nine senior retail academics and eight practitioners, selected using purposive sampling. The academic sample represented nine different UK Universities, all of whom are prominent in the field of UK retail academic research. The eight retail practitioners, who were identified through professional and personal contacts, were all in senior management positions and represented large retail organisations operating in different markets ranging from health and beauty, furniture, confectionary, fashion and games as detailed in Table 2. Academics 
are only identified as 1-9 in the study as to reveal any detailed information around their position and University could breach confidentiality.

INSERT TABLE 2 HERE

The instrument used to collect the data were semi-structured interviews with both sets of participants. Eight of the nine academic interviews took place face to face with one interview conducted by telephone. The eight retail practitioner interviews were all conducted in face to face meetings. The interviews, which were around 45 mins duration, were undertaken by one member of the research team to provide consistency of data capture.

All participants were provided with details of the purpose of the study and an outline of the interview. The interview guide included questions relating to definitions of academic research, its role in contributing to knowledge, its relevance to retail practice, how both parties communicated and related to each other and the ways in which academic research could be used to inform retail practice. Specific questions explored the existence of the RM antecedents in Table 1. These included questions about the benefits and importance of research collaboration and barriers to effective interaction. Data from the in-depth interviews, which were all recorded and transcribed, amounted to over 150 pages of text. Then, Template Analysis was used to identify key themes in the data (Crabtree and Miller, 1999), using the detailed categories provided in the RMM framework outlined in Table 1 Template analysis was considered to be appropriate as an analytical approach suited to comparative evaluation of different groups of people, or individuals, within a specific context (King, 2004). The list of codes (the 'template') helps the researcher make sense of large amounts of rich textual data via the use of structured and systematic analytical methods (Waring and Wainwright, 2008). Each research team member read the data sets several times and segmented the text into sections relating to the nine antecedent of the RMM framework. In depth examination of the sections then followed to generate line by line coding and categories, which were assigned to the relationship marketing antecedents identified in Table 1. Finally, relying on the multiple sources of evidence detailed above, the data was converged and triangulated to address the questions detailed in Table 1.

\section{Findings and discussion}

In the original RMMF, although there is widespread disagreement about which combination of relational antecedents, mediators and moderators affect which performance outcomes, there is some consensus around the antecedents required for effective relationship development. These antecedents provide the focus for the discussion of the findings. The discussion draws on the full dataset and Table 3 (included as an appendix) provides quotes from interview respondents which relate to the key antecedents.

\section{Relationship benefits and dependencies}

According to the Dowling Review, (2015) business-university research collaborations provide 'a myriad of benefits to their participants'. For business, these could include improved business performance through the application of new technologies, better decision making and enhanced internal research capability and expertise. For academics, the benefits cited include access to new skills, and the opportunity to address challenging research questions with real world applications and see research have a tangible impact (p.2). The findings here 
however suggest that many of these benefits are neither recognised nor appreciated by academics and businesses in the retail sector. This lack of mutual understanding is succinctly articulated in the following:

'I don't think there's an awareness of what one could do for the other, and that's a two way street. The gap exists because I don't think there's an awareness of what the benefits might be' (Retailer 4).

Furthermore although academic participants can articulate what characterises high quality academic research in terms of 'robustness and defensibility of its own conclusion' and research which 'extends a body of knowledge' and gives a 'theoretical contribution', there was no strong evidence that these particular qualities are valued by the retail business community. Indeed the issue of theoretical contribution continues to be seen as a potential barrier by some.

'My view on academic research is perhaps not very well informed but I see it as distant from reality' (Retailer 3).

Academics clearly recognise that this is a perception held by many retailers. Academics themselves admit that much academic research 'bears little relationship to the real world of retailing' (Academic 5) and that 'by and large (retailers) will find the research outputs of retailers fairly obscure' (Academic 1 ).

From an academic perspective the potential to collaborate to generate tangible research impact, although recognised, appears not to be universally valued. Although the Research Excellence Framework (i.e. REF 2014) highlights the importance of academics being able to co-create knowledge with 'impact', the rewards associated with this engagement are limited. For example, research published in outlets accessed by retailers receive little reward in the current REF and other research publication acknowledgment systems. As Academic 1 noted: 'If you get anything that's remotely of interest to practitioners then its ranked very, very low in terms of academic journal output'. For academics publishing in the retail area, the problem is exacerbated by the limited number of retail journals classified as 'internationally excellent' in quality ranking lists. 'At the end of the day it comes back to reward and how you get on in academia and it's still very much balanced towards this academic publication' (Academic 9)

In terms of dependency, it is clear that in most cases academia is not the first port of call for Retailers trying to access research resource. As well as their own expanding 'big' datasets on consumer behaviour drawn from loyalty cards and transaction data, they increasingly have access to an extensive array of research and information supplied by commercial consultancies, trade publications and conference organisations. Commercial consultancies, such as Experian, IGD, PwC and Deloitte, who have established reputations in retail consultancy, appear to have appropriated a 'middle ground' between academia and practice by offering a wealth of relevant retail data presented in a rigorous yet easily digestible format as articulated by Retailer 8 
'We use a number of industry wide sources... we are very data rich in terms of our sources', with Retailer 5 adding that 'If we need an insight on marketing for example we would not go to an academic for that, we would go to an agency'.

Linked to the discussion above, the benefits of academic research over commercial outputs have not been clearly articulated or 'sold' to retailers. Although the added value of academic research in terms of quality and interdisciplinary insight might be well understood within the academic community, retailers clearly assess quality differently, looking for information to support fast decision making rather than a contribution to knowledge at a more abstract level.

As Academic 5 commented 'Retailers I think are much more solutions focused, they're by necessity more short-term in the way that they think about things. And they're much more focused on achieving solutions on time, within budget, and with ... yeah, and are prepared to accept caveats to the quality of what's done as a consequence of that'.

In addition to commercial retail consultancies, most major retailers have expanded their incompany research capability to work on the increasing volumes of market and consumer data now being generated by via their own mobile applications and online shopping consumer datasets. In theory this should increase the retailers' dependency on academia, as a potential source of graduates and postgraduates with digital skillsets. The value proposition lies more in providing students who can help retailers to analyse their own data rather than doing the research for them and presenting it to retailers. Retailers have always valued the academic relationship as a recruitment arena for the students and is something that could be developed within the research space. The recently established ESRC Consumer Data Research Centre (CDRC) a collaboration between UCL and Leeds University appears to be responding to this switch in emphasis. In recognition of the fact that retailers now have access to their own datasets they are offering collaborators access to skilled researchers (data analysts) to work on projects in exchange for anonymised data. The benefit for retailers focuses on getting access to highly specialised academic researchers with superior data analysis skills rather than research per se.

\section{Incentives and expertise}

As noted above the incentives for academics to invest time in research collaborations with retailers are limited. As well as the lack of rewards for publishing research in practitioner journals there appears to be little support or encouragement for 'secondments' or placements with retailers to access new skills and knowledge. This appears to be a situation which had deteriorated rather than improved. 'When I came into academia we would take people from business backgrounds and turn them into academics. Most universities don't do this now because they are geared to purely academic writing for academics' (Academic 2) It is certainly not the case currently that 'for academics in relevant disciplines, spending time in industry should be seen as a mark of esteem that enriches their career, analogous to gaining international experience' (Dowling p.35)

Despite the increasing use of external research agencies it is clear that retailers do value academia for certain types of expertise. 'I have used academic research for something very specific and which required specialised knowledge' (Retailer 6). For example 'there is quite a healthy engagement between major retailers and academics on store location analysis but 
they (the retail staff involved) are modellers, numbers guys, operational researchers and so they have a natural affinity with that kind of thing' (Academic 2). These links have led to the establishment of a number of well- regarded retail research centres and units at certain Universities such as Southampton and Oxford. (Cassidy et al 2013). Academic 5 recognised that 'there are a few Universities recognised as key centres with established links to retail'.

However, there is a concern that many of these centres, tied logically to business schools, are unable to showcase the full range of research being carried out in other university departments which might be relevant to retailers. Despite calls for more interdisciplinary collaboration many academics working outside business schools do not seem fully aware of (or indeed in some cases, motivated to consider) the value of their work to retailers. (Cassidy et al 2013). Even where there was an established relationship between a retailer and an individual academic researcher or research group, there appeared to be little evidence of any purposeful or active "cross selling" to that retailer of other relevant specialist research skills from the same University or Business School.

Interestingly, a number of retailers valued academic expertise which they could source locally. 'We don't use academic research in the organisation but (if we did) I would naturally look at universities in the local cities (Retailer 7). A small number of universities have capitalised very successfully on local research collaborations with key retailers e.g. Leeds University/Marks \& Spencer and Nottingham Universities/Alliance Boots but this remains an area for further development.

It is clear that as well as recognised centres of expertise, retailers have located individuals who they trust to operate effectively in both retail and academic environments. Our respondents named these individuals and it was clear that they were critical 'boundary spanners', driving collaboration and relationships in both contexts. They clearly possess a unique skill set, developed often through practical experience in both environments. For the most part however, our respondents considered there to be very little similarity between academics and retailers with both operating in very different cultural contexts, with different drivers, timescales and priorities. Retailers are generally interested in research to help drive sales and profit and ultimately improve financial performance. The academic is motivated to publish in high level academic journals. The retailers in our study considered academics to be 'distant from reality' and academics admit that they can be seen as having 'their heads in the clouds'. The differences are captured in this observation

'If you knew a practitioner you wouldn't invite them along to an academic conference, unless you were very sure that they were a particular type of person who was interested in that kind of academic approach' (Academic 3).

The development of critical personal relationships is undoubtedly hampered by relatively high staff turnover in the UK retail sector. The extremely competitive nature of the UK retail sector means that many senior staff move from one retail organisation to another on a frequent basis. As these are often the individuals charged with developing research, the movement can be quite disruptive. Time taken to harness and cement a relationship with a 
specific retailer can come to nothing when the key contact leaves for a different role in the same or another retail organisation.

\section{Communication and speed of response}

For retailers, a clear benefit from any research relationship is that findings can be delivered at speed and serve as a stimulus for action. Once again, the evidence suggests that academic research seems to be failing to deliver here. 'You have got a very fast moving (retail) environment. You can't afford to wait for 6 months of academic research: you need to get into a market at the time that it is needed' (Retailer 2).

Again, academics themselves recognised this issue blaming slow response times on a lack of institutional resource and bureaucratic processes and procedures: 'A lot of the information requirements that companies have, they want them satisfied in a short timescale and we just don't have the resource and the flexibility to be able to deliver within their timescale' (Academic 6)

The research reinforced the existence of poor and inappropriate communication as a major barrier to effective collaboration. There are limited occasions where retailers and academics meet face to face to discuss research collaboration with meetings typically take place within their own communities. 'I've personally organised conferences that were supposed to bring together retailers and they have only been attended by academics' (Academic 3). As noted above not only are most academic research outputs published in academic journals, to which retailers don't have access or time to read, but the findings are not presented in retail friendly language or in accessible formats. Although some journals provide a translation service for managers and highlights the key outputs in practitioner language e.g. Journal of Services Marketing, these are not publications retailers would normally access.

In addition, interestingly, our findings demonstrate that retailers view effective communication as an academic responsibility:

'Academics need to promote to business the benefit they can bring' if you don't tell people, they won't know. Academics need to be able to speak our language and understand what drives us as a business. Without that, no pitch would work' (Retailer 3) and as observed by Retailer 1 'At the end of the day unless academics have a good story to tell and unless they are providing some guidance or innovation, then it's going to be very hard to stimulate the interest of the retailers'

Although academics may not like to see themselves in the role of seller in the exchange relationship it is clear that this is a position that retailers feel they should adopt i.e. the onus is on the academic to forge the research relationship.

\section{Conclusion}

The overall aim of this study was to develop the understanding of the continuing 'gap' between retail academic research and practice. The analysis of the data with a RM lens has drawn attention to the persistence of many of the well documented barriers to effective collaboration as well as generated new insights. These new insights appear in all three areas of the discussion; relationship benefits and dependencies, incentives and expertise and communication and speed of response. In terms of benefits, it is unlikely that retailers will ever assess the quality of research in the same way that academics do. Their interest in 
rigorous methodology and theoretical development will always be overtaken by concerns for immediate impact and obvious 'take outs'. However the changing data landscape suggests that there is an opportunity for academics to refocus the benefit of a relationship around capacity development, providing a constant stream of highly skilled research graduates to enable retailers to better analyse their own big datasets. In RM terms, to become a valued supplier academia needs to reaffirm the distinctiveness of its research proposition. Either in terms of focusing on the potential impact of high quality research on decision making or on its position as a source of supply of researchers skilled in advanced data analytics. In terms of incentives, the evidence suggests that despite the focus on impact within the REF framework, many academics remain sceptical about the benefits of research collaboration. There is a widely held perception that internal reward structures are heavily skewed towards outputs in academic journals rather than retail publications. Although this in itself is not new, what is surprising is the lack of motivation or apathy towards any change to the situation. The fact that this perception is so prevalent and enduring suggests that drastic action is required by HEl's make any significant change. This is a point reinforced by the Dowling which called for Universities 'to ensure that recruitment and promotion criteria for relevant disciplines reward rather than penalise academics who have achieved excellence in translational and collaborative activities' (p.30). On a more positive note the research highlights the critical role played by 'boundary spanners' within the retail research context and the fact that certain pockets of expertise are highly valued by the retail community. In particular universities are perceived to play a valuable role as a local source of supply for many retailers. All of these issues offer potential avenues for further research as well as platforms to promote academic excellence to retailers. In terms of communication perhaps the most interesting finding relates to the fact that retailers view this as the sole responsibility of the academic community. Academics are expected to be able to present their research in the lexicon of retail. Again this suggests that institutional resources need to be invested to support and reward effective translation and dissemination activities of academics.

Through the use of a RM lens, the contribution of this study has been to draw out new insights into the potential causes of the weak research relationship between retail academics and practitioners. These include insights about relationship benefits and dependencies, rewards and expertise and communication. The findings here also support a number of the key barriers to collaboration already identified in the mainstream management literature which is testament to their enduring nature. The fact that there are problems identifying almost all of the requisite relationship antecedents, suggests that significant and urgent action will be required if significant progress is to be made closing the gap. The Dowling Report (2015) identified many of the same problems highlighted in our research. The Report sends out a call to arms and recommends that individuals who can work in both business and academia and who are able to achieve collaborative and translational activities need to be valued, and recommends that for an academic, gaining experience in industry should be considered career enriching recognising that 'crossing the divide' requires skill but builds expertise and experience, (p.34)

Implications for Practice 
Based on our research we suggest several urgent actions are needed. The most important of which is that Universities actively adopt a relationship marketing strategy to foster engagement between academics and retailers focusing on the key relationship antecedents identified in this research. Communication from academics should emphasise the benefits which are valued by retailers. These might include, for example, specialist expertise in data analysis, access to the wider resources available in universities, including cross-disciplinary and international research links. In addition, key 'boundary spanners' who are currently active and respected within the academic and practitioner communities need to be identified and rewarded. As yet there does not appear to have been any systemic attempt to profile these individuals to identify relevant skill sets and experience to guide future recruitment. Consideration also needs to be given to reshaping the reward structure associated with the impact agenda to balance the reward awarded for output published in academic and practitioner journals. Academics should also consider proactively developing relevant research projects to promote to practitioners, based around the known key challenges facing UK retail. Recruitment of retail academics should also favour those with industry experience who can communicate with practitioners in relevant terms and language. Finally, the appointment of relationship (account) managers within UK Universities or Business Schools would help ensure long term, more frequent interactions with all areas of business (including retail) and the higher education community.

In addition to the implications for practice, our study has generated a list of interesting research questions which require further examination. First; in what ways does research provided by commercial agencies differ from that offered by academics? There is clearly a perception amongst academics that academic research is of higher quality, but what exactly does this mean and how might these differences be meaningfully communicated to retailers? Second; what characterises a successful sustainable research relationship between retail academics and practitioners? Is it due to the leadership of those involved, the nature of the topic or the level of institutional support and encouragement? It is clear that such relationships do exist but there is little evidence that they have been empirically investigated. Third; 'boundary spanners' clearly exist who have the necessary skills sets to operate effectively in both cultures. Yet again we know very little about the nature of the skill sets and experience which make these individuals so effective

\section{Limitations}

The primary data was limited to a small sample of academics and practitioners and as such the findings are not necessarily generalizable.

\section{References}

Anderson, E. and Weitz, B.A. (1989), "Determinants of Continuity in Conventional Industrial Channel Dyads," Marketing Science, Vol. 8 (Fall), pp. 310-23.

Anderson, E. and Weitz, B.A. (1992), "The Use of Pledges to Build and Sustain Commitment in Distribution Channels," Journal of Marketing Research, Vol. 29 (February), pp.18-34.

Baron, S., Richardson, B., Earles, D.and Khogeer, Y. (2011) "Marketing practitioners: Towards togetherness." Journal of Customer Behaviour, Vol. 10 (3), pp.291-304. 
Bartunek, J. (2011) "What has happened to Mode 2?" British Journal of Management, Vol. 22 (3), pp. 555-558.

BIS (2015). 'The Dowling Review of Business-University Research Collaborations' [online] Available at:

https://www.gov.uk/government/uploads/system/uploads/attachment_data/file/440927/b is_15_352_The_dowling_review_of_business-university_rearch_collaborations_2.pdf [Accessed: 15 May 2016]

BIS (2013) “A Strategy for Future Retail - Industry and Government Delivering in Partnership" [online]. Available at https://www.gov.uk/government/uploads/system/uploads/attachment_data/file/252383/b is-13-1204-a-strategy-for-future-retail-industry-and-government-delivering-inpartnership.pdf [Accessed on 13 October 2015]

BIS (2012) 'UK Retail Strategy' [online] Available at https://www.gov.uk/government/publications/bis-retail-strategy [Accessed on 12 October 2015]

Burt, S., Sparks, L. and Teller, C. (2010) "Retailing in the United Kingdom - a synopsis". European Retail Research, Vol. 24 (1), pp. 175-196.

Bryman, A. (2008) Research Methods and Organization Studies. London: Routledge.

Cassidy, K., Resnick, S. and Whysall, P. (2013) "Retail Navigator Project - Final Report" Economic \& Social Research Council, February 2013.

Crabtree, B. F. and Miller, W.L. (1999) Doing Qualitative Research. Sage Publications. London.

Crosby, L. A., Evans, K. R. and Cowles, D. (1990), "Relationship Quality in Services Selling: An Interpersonal Influence Perspective," Journal of Marketing, Vol. 54 (July), pp. 68-81.

Doney, P.M. and Cannon, J.P. (1997), "An Examination of the Nature of Trust in BuyerSeller Relationships," Journal of Marketing, Vol. 61 (April), pp. 35-51.

Dowling Review of Business-University Research Collaborations (2015) [online] Available at https://www.gov.uk/government/uploads/system/uploads/attachment_data/file/440927/b is_15_352_The_dowling_review_of_business-university_rearch_collaborations_2.pdf [Accessed: 21 June 2016]

De Wulf, K., Odekerken-Schröder, G. and Iacobucci, D. (2001), "Investments in Consumer Relationships: A Cross- Country and Cross-Industry Exploration," Journal of Marketing, Vol. 65 (October), pp. 33-50. 
ESRC (2013) Press Release 6 December 2013 [online] Available at 'New initiative will research ways to support the British retail sector' [online] Available at: http://www.esrc.ac.uk/news-events-and-publications/news/news-items/new-initiative-willresearch-ways-to-support-the-british-retail-sector/ [Accessed: 23 October 2015]

Fisher, C., 2007. Researching and writing a dissertation: a guidebook for business students. Pearson Education.

Ganesan, S. (1994), "Determinants of Long-Term Orientation in Buyer-Seller Relationships," Journal of Marketing, Vol. 58 (2), pp.1-19.

Geuens M. (2011), "Where does business research go from here? Food-for-thought on academic papers in business research." Journal of Business Research, Vol. 64(10), pp.11041107.

Guardian (2011) "Retail crisis: what the analysts say" [online] Available at http://www.theguardian.com/business/2011/jun/28/retail-crisis-what-the-analysts-say [Accessed on 12 October 2015]

Hennig-Thurau, T., Gwinner, K. P. and Gremler, D. D. (2002), “Understanding Relationship Marketing Outcomes: An Integration of Relational Benefits and Relationship Quality," Journal of Service Research, Vol. 4 (February), pp. 230-47.

Hibbard, J. D., Kumar, N. and Stern, L. W (2001), "Examining the Impact of Destructive Acts in Marketing Channel Relationships,"Journal of Marketing Research, Vol. 38 (February), pp. 45-61.

Hughes, T., O'Regan, N. and Wornham, D (2008) “The credibility issue: closing the academic/practitioner gap". Strategic Change, Vol. 17, pp.215-233.

Hunt, S. D. (2015) "The bases of power approach to channel relationships: has marketing's scholarship been misguided?",Journal of Marketing Management, Vol, 31(7-8), pp.747-764.

King, N. (2004). Using templates in the thematic analysis of text. In C. Cassell and G. Symon (Eds), Essential Guide to Qualitative Methods in Organizational Research, Sage, London, pp. 256-270.

Kumar, N., Scheer, L. K and Steenkamp, J. B. (1995), "The Effects of Supplier Fairness on Vulnerable Resellers," Journal of Marketing Research, Vol. 32 (February), pp. 54-65.

Lagace, R. R., Dahlstrom, R and Gassenheimer, J. B (1991), "The Relevance of Ethical Salesperson Behavior on Relationship Quality: The Pharmaceutical Industry," Journal of Personal Selling \& Sales Management, Vol. 11 (Fall), pp. 39-47.

Lee, N. and Greenley, G. (2010) "The theory-practice divide: thoughts from the Editors and Senior Advisory Board of EJM", European Journal of Marketing, Vol. 44 (1/2), pp.5 -20. 
Markides, S. (2007) "In search of ambidextrous professors". Academy of Management Journal, Vol. 50(4), pp. 762-768.

Mintel-Oxygen (2011) Online Spending Habits UK. February 2011 [online]

Available at http://store.mintel.com/online-spending-habits-uk-february-2011

[Accessed 20 December 2015]

Mohr, J. J., Fisher, R. J. and Nevin, J. R. (1996), "Collaborative Communication in Interfirm Relationships: Moderating Effects of Integration and Control," Journal of Marketing, Vol. 60 (July), pp. 103-115.

Morgan, R. M. and Hunt, S. D. (1994), "The Commitment-Trust Theory of Relationship Marketing," Journal of Marketing, Vol. 58 (July), pp. 20-38.

Nkomo, S. (2009) "The seductive power of academic journal rankings: Challenges of searching for the otherwise", Academy of Management Learning and Education, Vol.8, pp.106-112.

O'Donnell, A. and Cummins, D. (1999) "The use of qualitative methods to research networking in SMEs". Qualitative Market Research: An International Journal, 2, (2), pp. 82 91.

Palmatier, R. W., Dant, R.P., Grewal, D and Evans, K.R. (2006) 'Factors Influencing the Effectiveness of Relationship Marketing: A Meta-Analysis,' Journal of Marketing, Vol.70 (October), pp.136-153.

Pfeffer, J. and Sutton, B. (1999) "Managing half-truths". California Management Review, Vol. 48(3), pp. 77-100.

Raconteur (2015) "Future of Retail" published in the Sunday Times on 21 June 2015 in association with The British Retail Consortium [online] Available at http://raconteur.net/archive [Accessed on 15 October 2015]

Raconteur (2016) "Future of Retail" published in the Sunday Times on 29 May 2016 in association with The British Retail Consortium [online] Available at http://raconteur.net/archive [Accessed on 1 July 2016]

Research Excellence Framework (REF) 2014 [online] Available at http://www.ref.ac.uk/ [Accessed on 12 October 2015]

Rynes, S. L., Giluk, T. L., and Brown, K. G. (2007). "The very separate worlds of academic and practitioner publications in human resource management: Implications for evidence-based management", Academy of Management Journal, Vol. 50, pp.987-1008.

Sheth, J. N. (2015)" The future evolution of Relationship Marketing" in Morgan, R. M., Turner, J and Parish, G.D. (Eds.) Handbook on Research in Relationship Marketing, Edward Elgar Publishing, London. Chapter 1 
Tynan, C. (1997) "A Review of the Marriage Analogy in Relationship Marketing." Journal of Marketing Management, Vol. 13 (7), pp. 695-703.

Vincent, N. A. and Webster, C. M. (2013),"Exploring relationship marketing in membership associations", European Journal of Marketing, Vol. 47 (10), pp. 1622 - 1640.

Waring, T., and Wainwright, D. (2008) "Issues and challenges in the use of template analysis: two comparative case studies from the field", The Electronic Journal of Business Research Methods, Vol. 6 (1), pp. 85-94.

Wood, S., Adams, R., Lowe, M., and Neely, A. (2008) "Study of Contemporary and Future Challenges in the UK Retail Sector" [online] Available at http://www.aimresearch.org/ourresearch/business-engagement-project/BEP-retail-sector [Accessed November 2015]

INSERT TABLE 3 HERE 


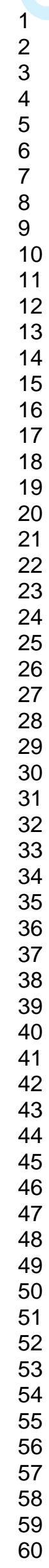


Table 1 RM Antecedents and Retail Relevance (adapted from Palmatier et al, 2006)

\begin{tabular}{|c|c|c|}
\hline Antecedents & Representative Papers & Relevance to retail academics and practitioners \\
\hline \multicolumn{3}{|l|}{$\begin{array}{l}\text { CUSTOMER } \\
\text { FOCUSED }\end{array}$} \\
\hline $\begin{array}{l}\text { Relationship } \\
\text { benefits }\end{array}$ & $\begin{array}{l}\text { Morgan and Hunt } \\
\text { 1994; Hennig-Thurau, } \\
\text { Gwinner, } \\
\text { Gremler } 2002\end{array}$ & $\begin{array}{l}\text { To what extent do academics feel the need to develop } \\
\text { a relationship in the first place? i.e. how important is it? } \\
\text { To what extent do retail practitioners understand and } \\
\text { appreciate the benefits of research collaboration? }\end{array}$ \\
\hline $\begin{array}{l}\text { Dependence on } \\
\text { seller }\end{array}$ & $\begin{array}{l}\text { Morgan and Hunt 1994; } \\
\text { Hibbard, Kumar, Stern } 2001\end{array}$ & $\begin{array}{l}\text { How important is the research relationship to retailers? } \\
\text { What are the alternative sources of supply? How are } \\
\text { they perceived relative to academic sources? } \\
\text { What benefits are offered by alternative suppliers? } \\
\text { How effectively are these benefits articulated and } \\
\text { communicated by academics to retailers? }\end{array}$ \\
\hline SELLER-FOCUSED & 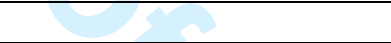 & \\
\hline $\begin{array}{l}\text { Relationship } \\
\text { investment }\end{array}$ & $\begin{array}{l}\text { Ganesan } \\
\text { 1994; De Wulf, Odekerken- } \\
\text { Schröder, } \\
\text { lacobucci } 2001\end{array}$ & $\begin{array}{l}\text { How much time and effort do academics devote to } \\
\text { developing the relationship? } \\
\text { What incentives are used to encourage and develop } \\
\text { exchange relationships? }\end{array}$ \\
\hline Seller expertise & $\begin{array}{l}\text { Crosby, Evans, and Cowles } \\
\text { 1990; } \\
\text { Lagace, Dahlstrom, } \\
\text { Gassenheimer } 1991\end{array}$ & $\begin{array}{l}\text { How do retailers rate the knowledge and expertise of } \\
\text { academic researchers? } \\
\text { Are there particular areas of specialism which are } \\
\text { valued more highly than others? }\end{array}$ \\
\hline \multicolumn{3}{|l|}{ DYADIC } \\
\hline Communication & $\begin{array}{l}\text { Morgan } \\
\text { and Hunt 1994; Mohr, } \\
\text { Fisher, Nevin } 1996\end{array}$ & $\begin{array}{l}\text { What form does research communication take? How } \\
\text { effective is it? } \\
\text { What do we know about the quality of information } \\
\text { being 'shared'/communicated? }\end{array}$ \\
\hline Similarity & $\begin{array}{l}\text { Morgan and Hunt 1994; } \\
\text { Doney and Cannon } 1997\end{array}$ & $\begin{array}{l}\text { How much do individuals involved in undertaking and } \\
\text { commissioning research have in common? Do they } \\
\text { have similar backgrounds, lifestyles, experiences? } \\
\text { Are there many cultural similarities between the two } \\
\text { sets of organisations? }\end{array}$ \\
\hline $\begin{array}{l}\text { Relationship } \\
\text { duration and } \\
\text { interaction } \\
\text { frequency }\end{array}$ & $\begin{array}{l}\text { Anderson and Weitz 1989; } \\
\text { Doney and Cannon } 1997 \\
\text { Crosby, Evans, Cowles 1990; } \\
\text { Doney and Cannon } 1997\end{array}$ & $\begin{array}{l}\text { How long have relationships existed? } \\
\text { How long do they tend to last? } \\
\text { How frequently do research partners get together? } \\
\text { How long do interactions last? }\end{array}$ \\
\hline Conflict & $\begin{array}{l}\text { Anderson and Weitz 1992; } \\
\text { Kumar, Scheer, Steenkamp } \\
1995\end{array}$ & $\begin{array}{l}\text { What are the areas of disagreement between the two } \\
\text { parties? } \\
\text { How does this conflict manifest itself? }\end{array}$ \\
\hline
\end{tabular}


Table 2 Retail Participant Companies

\begin{tabular}{|l|l|l|}
\hline Participant & Market Sector & Role \\
\hline 1 & Health and Beauty & Director \\
\hline 2 & Clothing & Chairman \\
\hline 3 & Confectionary & CEO \\
\hline 4 & Children's Clothing & Director \\
\hline 5 & Furniture & CEO \\
\hline 6 & Toys and Games & CEO \\
\hline 7 & Shoes & Director \\
\hline 8 & Opticians & Director \\
\hline
\end{tabular}


Table 3 Retail Practitioner and Academic Commentary

\begin{tabular}{|c|c|c|c|}
\hline Antecedents & Definition & Evidence from retailers (customers) & Evidence from Academics (sellers) \\
\hline $\begin{array}{l}\text { Customer focused } \\
\text { Relationship benefits }\end{array}$ & $\begin{array}{l}\text { Perceive value in a } \\
\text { relationship: time saving, } \\
\text { convenience. } \\
\text { companionship, and } \\
\text { improved decision } \\
\text { making } \\
\text { Customers evaluation of } \\
\text { the value of resources } \\
\text { for which few } \\
\text { alternatives are available } \\
\text { from the seller }\end{array}$ & $\begin{array}{l}\text { 'Retail is very fast paced; its very quick moving; academic research has } \\
\text { this image of being very slow' } \\
\text { 'A research application process that takes } 26 \text { weeks to approve is } \\
\text { inconsistent with our timescales' } \\
\text { 'If we (retailers) need an answer, if there's a problem that we need an } \\
\text { answer to, we need it next week or we need it yesterday' } \\
\text { 'We use a number of industry wide sources... we are very data rich in } \\
\text { terms of our sources' } \\
\text { 'So the timelines that you guys (academics) run to are not the timelines } \\
\text { that a consultant might run to so you're not particularly relevant for us' }\end{array}$ & $\begin{array}{l}\text { 'By and large (retailers) will find the research } \\
\text { outputs of retailers fairly obscure, very } \\
\text { difficult to understand so there's a need for } \\
\text { that interpretation'. } \\
\text { 'One of the key drivers for all academia but } \\
\text { our institution as well included, is to gain } \\
\text { outputs in peer reviewed journals' } \\
\text { 'The perception is that the research we are } \\
\text { involved in is abstract and bears little } \\
\text { relationship to the real world of retailing' } \\
\text { 'Retailers want short projects for which they } \\
\text { are using consultants' }\end{array}$ \\
\hline $\begin{array}{l}\text { Seller focused } \\
\text { Relationship } \\
\text { investment }\end{array}$ & $\begin{array}{l}\text { Investment of time, } \\
\text { effort, spending, and } \\
\text { resources focused on } \\
\text { building a stronger } \\
\text { relationship } \\
\text { Knowledge, experience } \\
\text { and overall competency } \\
\text { of seller }\end{array}$ & $\begin{array}{l}\text { 'Academic research not always relevant to a specific business and } \\
\text { involves a lot of time invested that was of limited value' }\end{array}$ & $\begin{array}{l}\text { 'They're not addressing the day to day needs } \\
\text { of the industry' } \\
\text { 'Retailers appear to hold a general level of } \\
\text { respect for the research skills and expertise of } \\
\text { academic' }\end{array}$ \\
\hline $\begin{array}{l}\text { Dyadic } \\
\text { Communication }\end{array}$ & $\begin{array}{l}\text { Amount, frequency and } \\
\text { quality of information } \\
\text { shared between } \\
\text { exchange partners } \\
\text { Commonality in } \\
\text { appearance, lifestyle, }\end{array}$ & $\begin{array}{l}\text { 'My view on academic research is perhaps not very well informed, but I } \\
\text { see it as distant from reality if I was to be crude about it' }\end{array}$ & $\begin{array}{l}\text { 'Retailers do not want a 'rated journal speak' } \\
\text { 'In my opinion most retailers don't have much } \\
\text { idea of how to access academia' } \\
\text { 'It's a bit of an uphill struggle though because } \\
\text { the mindset of a lot of guys in this area is that } \\
\text { academics have their heads in the clouds' }\end{array}$ \\
\hline
\end{tabular}




\begin{tabular}{|c|c|c|c|}
\hline & $\begin{array}{l}\text { and status between } \\
\text { individual boundary } \\
\text { spanners or similar } \\
\text { cultures, values, and } \\
\text { goals between buying } \\
\text { and selling organisations }\end{array}$ & & $\begin{array}{l}\text { 'There are some retailers who are very } \\
\text { engaged in academia but others who would } \\
\text { never talk to an academic' }\end{array}$ \\
\hline $\begin{array}{l}\text { Relationship duration } \\
\text { and Interaction } \\
\text { frequency }\end{array}$ & $\begin{array}{l}\text { Length of time that the } \\
\text { relationship between the } \\
\text { two has existed and the } \\
\text { number of interactions } \\
\text { or number of } \\
\text { interactions per unit of } \\
\text { time between exchange } \\
\text { partners }\end{array}$ & $\begin{array}{l}\text { 'Academic research not always relevant to a specific business and } \\
\text { involves a lot of time invested that was of limited value' } \\
\text { 'I don't have any dealings with the local University' }\end{array}$ & $\begin{array}{l}\text { 'There are a few Universities recognised as } \\
\text { key centres with established links to retail' } \\
\text { 'Retailers tend to move from post to post so } \\
\text { difficult to retain contact' }\end{array}$ \\
\hline Conflict & $\begin{array}{l}\text { Overall level of } \\
\text { disagreement between } \\
\text { exchange partners: } \\
\text { termed perceived or } \\
\text { manifest conflict }\end{array}$ & $\begin{array}{l}\text { 'Research in the retail sector is implemented by the retailer. The } \\
\text { objective is quite different' }\end{array}$ & $\begin{array}{l}\text { 'Divergence of academic and business } \\
\text { agendas-different timescales and } \\
\text { conceptualism' }\end{array}$ \\
\hline
\end{tabular}




\section{Letter to Reviewers}

First of all we would like to thank both reviewers for their positive feedback about significant aspects of the manuscript, in particular the support for our view that there is a lack of empirical evidence for the reasons why 'academics undertaking retail-related research have found it extremely hard to 'penetrate' the retail sector' (Reviewer 2)

There appear to be two areas of concern for the reviewers. These relate to the contribution of the paper and the use of the relationship marketing lens as our framework for analysis. We have addressed both of these concerns as follows:

\section{The contribution of the paper}

Both Reviewers are seeking clarity of the contribution and added value of the paper beyond the existing debate. Reviewer 2 asks us to 'do more to demonstrate the added value of the paper' and Reviewer 1 urges us to 'to make clear what the paper delivers beyond what was already well known'. Although we believe that our research has generated new insights we agree with both reviewers that these were not communicated very effectively in the original manuscript. We have taken both sets of comments extremely seriously and therefore made the following changes to the manuscript.

First; we have totally restructured and represented the material from pages 9 to 15 . The discussion now centres on three new headings; relationship benefits and dependencies; incentives and expertise; communication and speed of response. We believe these new headings, (which bring together the key RM antecedents in a similar way to the Customer Focussed, Seller Focused and Dyadic groupings in Pamatiers 2006 Framework ) help emphasise and reinforce the contribution of the paper and distil the new insights we have found. These headings replace the original narrative, which as you will recall followed the same key RM antecedents headings as those used in Table 1. We hope that with this new representation that we have addressed the concerns of Reviewer 2 that our discussion was 'brief' and the presentation of results read like a 'summary'

In addition, the contribution as detailed on page 5 now provides a clearer statement of our contribution and justification for the use of the RM lens.

We have now also included relevant evidence and extracts from the 2015 Dowling Review of Business-University Research Collaborations (on pages 5 and 9) as the messages from this major and recent review, commissioned by Government, reinforces the timeliness and significance of the contribution of our paper

Following advice from Reviewer 2, we have now extracted some of the original quotations from the interviews, included in Table 3, and incorporated them into this now more in depth and expanded discussion section In the discussion where we have also articulated more clearly which aspects of our research findings represent new insights; for example, the fact that retailers place more value on academia as a source of highly skilled research graduates, helping them to analyse their own big datasets, rather than in the ability of academia to carry out specific pieces of research.

\section{Justification of the interview research instrument's relationship with the relationship marketing}

We have expanded the methodology section, on pages 7 and 8 , to more clearly explain the relationship between the research instrument used in the interviews and the RM framework. This reflects a specific request made by Reviewer 1 who asked us to specifically explain how 'the instruments relate to the mapping of relationship marketing presented in Table 1. It is worth noting 
here that the data from the interviews forms only part of that used in our discussion where we have drawn on other significant sources of secondary data i.e. the recommendations made in the Final Report from the ESRC-funded Retail Navigator Initiative in 2013. We have also highlighted on page 5, and hopefully in much clearer terms, that the use of a RM lens to examine this academic-practitioner gap issue is both novel and highly relevant.

Finally to ensure the continued and contemporary relevance of the paper we have inserted some new evidence from page 1 of the most recent edition of the Raconteur Future of Retail which was published on 29 May 2016 which highlights some of the key profitability challenges facing the UK retail industry moving forward.

Can we thank both reviewers for the time taken to review this papers and for your considered and constructive comments and hope this revised paper now addresses your points.

Best wishes

The Authors 